\title{
Exhaust Heat Recovery and Performance Improvement of Jaggery Making Furnace
}

\author{
Appasaheb Manjare* and Jitendra Hole \\ ${ }^{\dagger}$ Rajarshi Shahu College of Engineering, Tathawade,SP Pune University, Mumbai, India
}

Accepted 15 June 2016, Available online 20 June 2016, Special Issue-5 (June 2016)

\begin{abstract}
Jaggery making from the sugarcane is a traditional process which creates local employments and entrepreneurship opportunities. Jaggery making plants are generally small units fabricated by local artisans on the basis of age old expertise without any technical support. Bagasse is used as fuel to boil the sugarcane juice. In traditional single pan jaggery furnace due to incomplete combustion of bagasse energy losses are high resulting into higher fuel consumption and low thermal efficiency of the plat. In order to reduce the losses and cut down the consumption of bagasse, exhaust heat is utilized for preheating of sugarcane juice in pre-heater. The improved plant and the conventional plant are compared on the basis of thermal efficiency and bagasse consumption per Kg jaggery production. Resulted that thermal efficiency is improved from $16.16 \%$ to $24.36 \%$ and bagasse consumption is reduced by $1.2 \mathrm{Kg}$ per Kg jaggery production.
\end{abstract}

Keywords: Bagasse, Boiling Pan, Economizer, Pre-heating, Single pan jaggery furnace, Thermal efficiency

\section{Introduction}

At present, 115 countries of the world cultivate sugarcane for sugar production and produce about 133 million tonnes of sugar and 10 million tonnes of jaggery. Brazil, India, China, Pakistan, USA, Australia, Thailand and Philippines are the some major sugarcane cultivating countries in the world. Sugarcane occupies an important position in agrarian economy of India. About 6 million farmers and a large number of agricultural labours are involved in cane cultivation. The area under sugarcane is hovering around 4.4 million hectares and with an average productivity of 68 tonnes/hectare. On an average, white sugar production accounts for nearly 60 percent of the total cane produced in the country, 15-20 percent sugarcane is utilized for Jaggery production and rest is utilized for other purposes including seed. Jaggery production in our country is a traditionally, labour- intensive cottage industry, mostly, confined to rural areas.

There is a general thought that jaggery is a common sweetener of the poor. However, it is fairly consumed in almost all sections of society. Jaggery is an ecofriendly sweetener and meets about 40 percent demand of sweeteners in the country. Jaggery has been in use as energy food and sweetening base for a number of preparations since the time immemorial. The important traditional sweetener is commonly known as Gur in India, Desi in Pakistan, Panela in South America and Jaggery in African countries.
Scientifically or technically defining, jaggery is an amorphous form of unrefined and non-distilled sugar prepared from juice of plants which contain considerable amount of sucrose or sugar in them, like sugarcane and. Sometimes it is also called Country Sugar, as it is prepared in households in rural areas of certain countries. It is also called molasses due to its semi-solid state. Chemically, it is $\mathrm{C}_{12} \mathrm{H}_{22} \mathrm{O}_{12}$.

\section{Problem Definition}

Jaggery making from the sugarcane is a traditional process which creates local employments and entrepreneurship opportunities. Jaggery making plants are generally small units fabricated by local artisans on the basis of age old expertise without any technical support. Bagasse is used as fuel for jaggery production. In traditional jaggery furnace due to incomplete combustion of bagasse energy losses are high resulting into higher fuel consumption and low thermal efficiency of the plant. In order to reduce the losses and cut down the consumption of bagasse, exhaust heat is utilized for preheating of sugarcane juice in pre-heater and economizer. The improved plant and the conventional plant are compared on the basis of thermal efficiency, bagasse consumption per kg jaggery production and production time. This project has a potential to reduce the fuel consumption and improve the thermal efficiency of the jaggery making furnace. 


\section{Jaggery Making Process}

Process of jaggery making is almost same in every part of the Indian sub-continent but there is a difference in the design of plants being used for jaggery making. In the northern Indian states of Uttar Pradesh and Uttarakhand, three pan jaggery making plant is popular, however in the state of Maharashtra single pan and four pan plants are popular. Jaggery making from the sugarcane is a traditional process which creates local employments and entrepreneurship opportunities .

Jaggery making plants are generally small units fabricated by local artisans on the basis of age old expertise without any technical support. It mainly consists of an underground furnace, like an open pan cooking stove (bigger version of a biomass based cooking stove) with a pan mounted on to it for evaporating the juice. The process flow diagram for jaggery plant is presented in Figure 1.

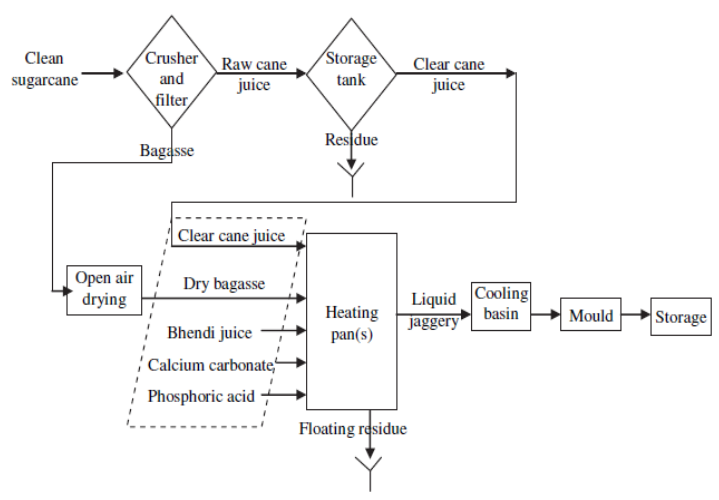

Figure 1: Process flow diagram for jaggery plant

Almost all the jaggery units use bagasse (a residue left after juice extraction from sugarcane) as a fuel to meet the energy requirement for the concentration of sugar cane juice. Bagasse is burnt in a furnace to provide required heat for evaporation of sugarcane juice. Variation in moisture content of sun dried bagasse affects performance of jaggery making furnaces. There are two types of jaggery furnace single pan furnace and multiple pans (Two to Four pans) furnace. In a single pan furnace all jaggery making processes like sensible heating, chemical addition, impurity removal, evaporation etc. are carried out in single pan as a batch process, while in a multiple pan furnace above jaggery making processes are carried out in three to four pans in a semi- continuous mode.

\section{Types of Jaggery Furnace}

\subsection{Single Pan Process}

Maharashtra has been one of the leading producers of jaggery in India since long time. Single pan method is most popular method for jaggery production. This is also known as Kolhapur Method. Unlike the four pan method this method employs only single pan. The rest structure is almost similar to four pan method. Bagasse is manually fed through fuel inlet into the furnace. These bagasse burns on a grid and provides heat to the pan kept above the furnace. The ash gets separated falls down from grid and is collected in ash pit. The ash pit is cleaned on regular basis.

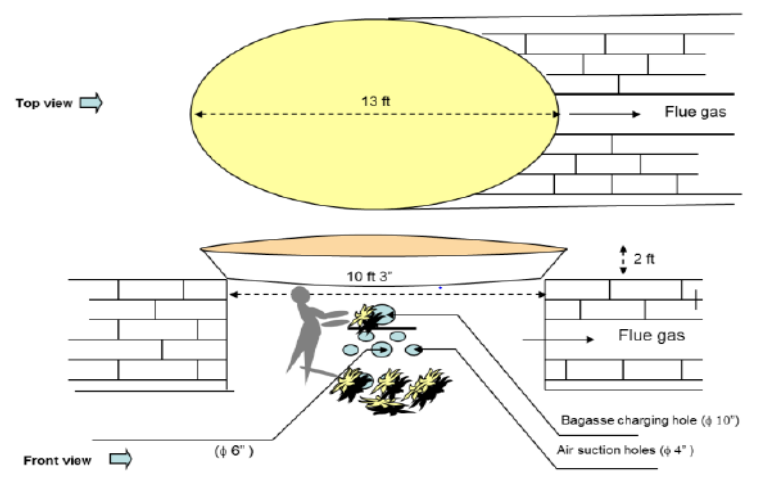

Figure 2: Single Pan Method

\subsection{Multi Pan Process}

This method is popular in Uttar Pradesh. In recent times with decreasing availability of labours the tendency of jaggery producer has been to sub-contract the plants to labours from Uttar Pradesh. These labours are skilled in using Four Pan method and consequently four pan method has become popular in these areas.

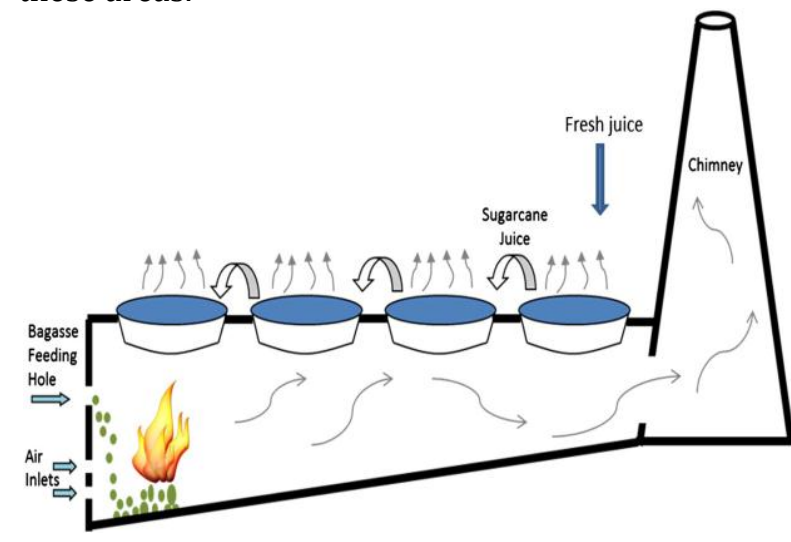

Figure 3: Multi-Pan Furnace

\section{Ideal Thermal Efficiency of Jaggery Furnace}

\subsection{Protocol of jaggery making process}

Fig.4 shows the sequence of steps through which the cane juice undergoes during the entire period. Cane juice contains non sugar components (e.g. proteins, pigments, poly phenols), which impart dark color and undesired taste to the final product, if not removed. Hence the removal of scum that floats over the liquid pool is commonly practiced in all the jaggery units. It has to be removed at three different stages of the process. This is the reason why the well known concept 
of multiple effect evaporation practiced in chemical plants, and performed under closed conditions, cannot be easily adopted for jaggery making process .

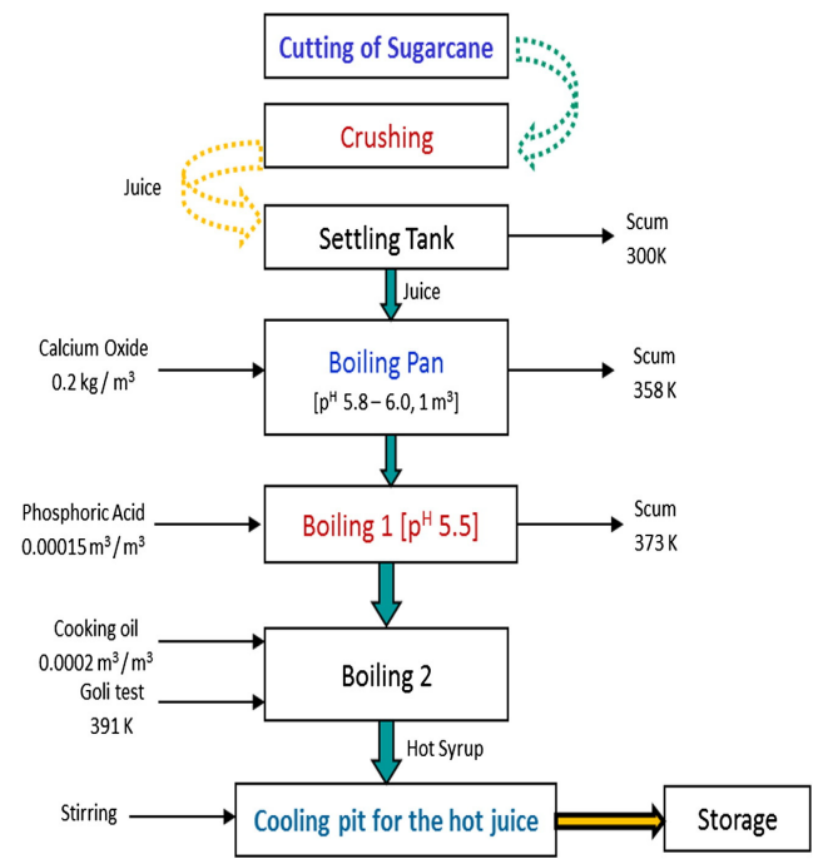

Figure 4: Protocol of jaggery making process

\subsection{Sugarcane Mass Balance:}

In order to evaluate the system performance of jaggery making furnace, various details such as juice recovery obtained after crushing sugarcane, amount of bagasse obtained, moisture contain in bagasse are shown in fig.5;

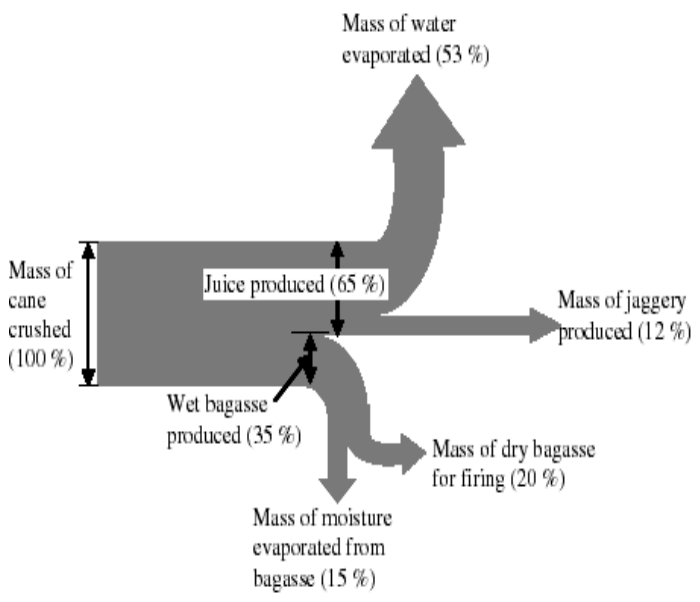

Figure 5: Mass Balance of Sugarcane

From sugarcane mass balance;

After heating of $5 \mathrm{Kg}$ of sugarcane juice, we get $1 \mathrm{Kg}$ of Jaggery and remaining $4 \mathrm{~kg}$ water gets evaporates;

Cp of water $=4.187 \mathrm{~kJ} / \mathrm{kgK}$, Cp of Jaggery $=2.0 \mathrm{~kJ} / \mathrm{KgK}$ Latent heat of water $=2270 \mathrm{~kJ} / \mathrm{kg}$ Energy required to produce $1 \mathrm{Kg}$ of Jaggery is;
$Q_{\text {utilized }}=$ Sensible Heat of water + Sensible heat of Jaggery + Latent Heat

$\mathrm{Q}_{\text {utilized }}=4^{*} 4.187 *(100-30)+1 * 2 *(118-30)+4 *$ 2270

$Q_{\text {utilized }}=10428 \mathrm{~kJ} / \mathrm{kg}$ of jiggery

\subsection{Heat Balance}

Part of the heat liberated by bagasse combustion $\left(Q_{\text {bagasse }}\right)$ is used in evaporation $\left(Q_{\text {utilized }}\right)$, and rest is lost along with the flue gas $\left(\mathrm{Q}_{\mathrm{fg}}\right)$ and through the walls $\left(\mathrm{Q}_{\mathrm{w}}\right)$ of the furnace. Hence, the heat balance is given as, $\mathrm{Q}_{\text {bagasse }}=\mathrm{Q}_{\text {utilized }}+\mathrm{Q}_{\mathrm{fg}}+\mathrm{Q}_{\mathrm{w}}$

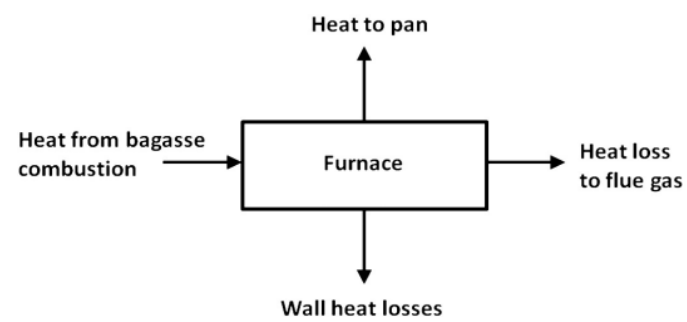

Figure 6: Heat balance for a furnace.

The heat loss from the furnace walls to the surrounding is,

$\mathrm{Qw}=\mathrm{h}_{\mathrm{a}} * \mathrm{Aw} *(\mathrm{Tw}-\mathrm{Ta})$

Where, $h_{a}$ is the convective heat transfer coefficient corresponding to losses to the surrounding. Here the furnace is surrounded by thick brick walls so these losses can be neglected for all practical purposes.

Bagasse is sugarcane fiber waste left after juice extraction. Bagasse is used as a fuel for Jaggery plant, when burned in quantity; it produces sufficient heat energy to fulfill all the needs.

A typical chemical analysis of bagasse show that moisture content of bagasse varies from 20 to $50 \%$, Ash from 1 to $4 \%$ and brix from 2 to $10 \%$.

Calorific Value of Bagasse $=[18260-207.63 *$ (moisture \% sample) $-182.6 *$ (ash \% sample) $-31.14 *$ (brix \% sample)] $\mathrm{kJ} / \mathrm{kg}$

At $10 \%$ moisture, $1 \%$ ash and $2 \%$ brix the calorific value of bagasse is equal to $16000 \mathrm{~kJ} / \mathrm{Kg}$.

The average formula for bagasse worked out to be $\mathrm{C}_{13} \mathrm{H}_{21} \mathrm{O}_{10}$ and hence the Stoichiometric reaction can be written as;

$4 \mathrm{C}_{13} \mathrm{H}_{21} \mathrm{O}_{10}+53 \mathrm{O}_{2}+53 *(79 / 21) \mathrm{N}_{2} \rightarrow 52 \mathrm{CO}_{2}+42 \mathrm{H}_{2} \mathrm{O}$ $+53 *(79 / 21) \mathrm{N}_{2}$

Mass of bagasse $=4 *(156+21+160)=4 * 337=1348$

Mass of air $=53 * 32+53 *(79 / 21) * 28=1696+5583$ $=7279$

Stoichiometric air $/$ fuel ratio $=7279 / 1348=5.4$

The heat loss through the flue gas, which is the major cause of energy inefficiency, is given as, 
$\mathrm{Qfg}=\left[\mathrm{mfg} * \mathrm{Cp}\left(\mathrm{T}_{\mathrm{fg}}-\mathrm{T}_{\mathrm{a}}\right)\right]_{\text {flue gas }}$

Flue gas $/ \mathrm{kg}$ of fuel $=$ air + fuel $=5.4+1$

Flue gas $/ \mathrm{kg}$ of fuel $=6.4 \mathrm{~kg} / \mathrm{kg}$ (fuel gets converted to $\mathrm{CO}_{2}$ and $\mathrm{H}_{2} \mathrm{O}$ )

Assuming flue gas exit temperature as $1000 \mathrm{~K}$ and ambient temperature as $300 \mathrm{~K}$,

Energy lost to flue gas $=6: 4 * 1 *(1000-300)$

Energy lost to flue gas $=4480 \mathrm{~kJ} / \mathrm{kg}$ of bagasse

Net energy from bagasse $=16000-4480=11520$

$\mathrm{kJ} / \mathrm{kg}$ of bagasse

Bagasse required $=10428 / 11520=0.9 \mathrm{~kg}$ bagasse $/ \mathrm{kg}$ of jaggery

Energy from bagasse $=Q_{\text {bagasse }}=0.9 * 16000=14400$

$\mathrm{kJ} / \mathrm{kg}$

Ideal thermal efficiency $=10428 / 14400=0.72$

Ideal thermal Efficiency $=72 \%$ [4]

\section{Traditional Jaggery Furnace}

In order to evaluate the system performance of jaggery making furnace, various details such as juice recovery obtained after crushing sugarcane, amount of bagasse obtained, the moisture content before and after sun drying, the amount and frequency of feeding bagasse into the furnace were noted. The temperature of juice during boiling and the temperature of flue gas were also observed.

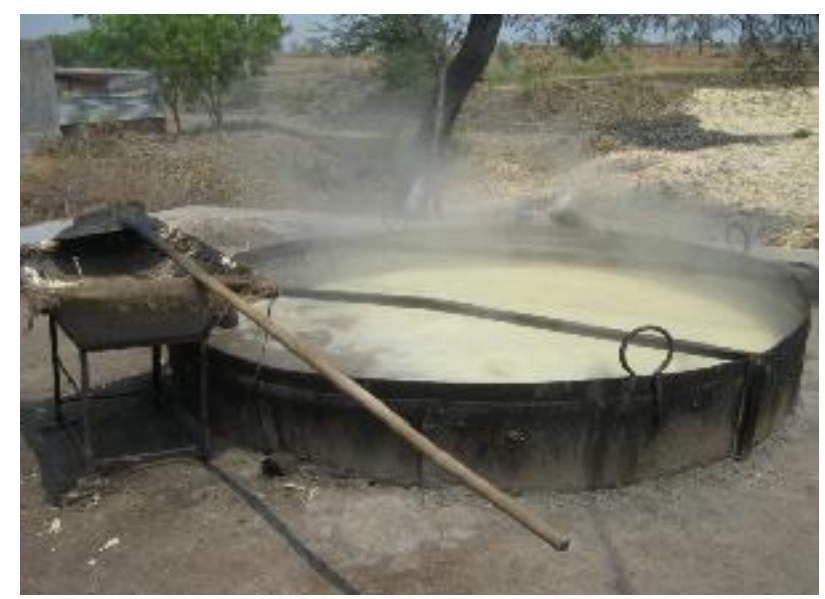

Figure 7: Traditional Jaggery Making Plant

\subsection{Observations}

i. Mass of sugarcane juice per batch $=840 \mathrm{~kg}$

ii. Mass of bagasse required per batch $=580 \mathrm{~kg}$

iii. Mass of jaggery produced per batch $=175 \mathrm{~kg}$

iv. Mass of slag (mud) removed per batch $=25 \mathrm{~kg}$

v. Mass of water evaporated per batch $=640 \mathrm{~kg}$

vi. Initial room temperature of furnace $=33^{\circ} \mathrm{C}$

vii. Initial temperature of juice $=30^{\circ} \mathrm{C}$

viii. Final temperature of juice $=95^{\circ} \mathrm{C}$

ix. Flue gas temperature near about $240^{\circ} \mathrm{C}$

$\mathrm{x}$. The inside temperature of furnace during combustion $=500$ to $600^{\circ} \mathrm{C}$

Time required for one batch $=2.5$ hours

\subsection{Calculations}

i) Heat energy input per batch $=m b * \mathrm{Cb}$

$$
=9280 \mathrm{MJ}
$$

ii) Energy required for heating the juice:

$$
\begin{aligned}
& =\mathrm{mj}^{*} \mathrm{CPw}^{*}(\mathrm{Tj}-\mathrm{Ta}) \\
& =218.05 \mathrm{MJ}
\end{aligned}
$$

Latent heat of water $=2270 \mathrm{~kJ} / \mathrm{kg}$

iii) Mass of water evaporated per batch:

Mass of jaggery produced $=$ mass of juice - mass of water evaporated - mass of slag

$$
\begin{aligned}
& 175=840-\mathrm{mw}-25 \\
& \mathrm{Mw}=640 \mathrm{~kg}
\end{aligned}
$$

iv) Total latent heat of vaporization of water :

$$
\begin{aligned}
& =\mathrm{Mw}^{*} \mathrm{~h}_{\mathrm{fg}} \\
& =640 * 2270 \\
& =1453.44 \mathrm{MJ}
\end{aligned}
$$

v) Total heat of evaporation required:

$=$ Heat energy required for heating the juice

+ Total latent heat of vaporization of water

$$
=218.05+1453.44
$$$$
=1671.49 \mathrm{MJ}
$$

vi) Thermal Efficiency = Heat output/Heat input

$$
=1671.49 / 9280
$$

Thermal efficiency $=16.16 \%[5]$

\section{Improved Jaggery furnace}

\subsection{Pre-Heater}

Tank is constructed around the chimney in which juice is poured. Juice absorbs the heat of the exhaust gas which is flowing through the chimney. It is observed that the temperature of the juice increased by $35^{\circ} \mathrm{C}$. Finally such heated juice poured in a boiling pan and efficiency calculated.

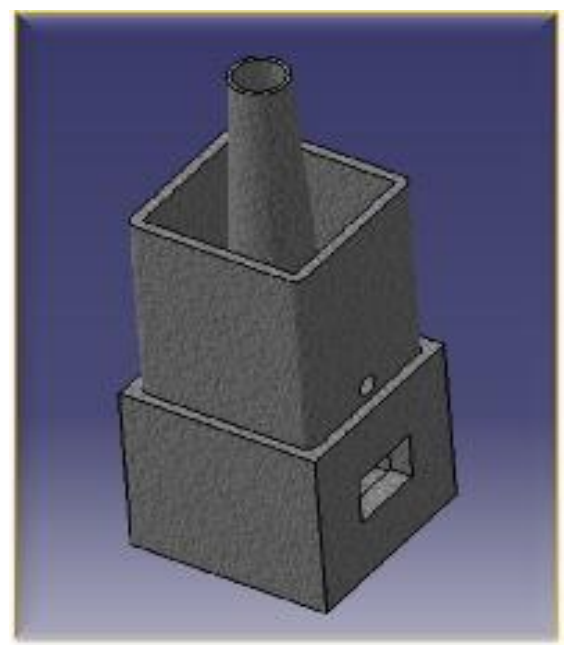

Figure 8: Modified chimney (Pre-Heater)

\subsection{Combustion chamber}

In improved jaggery plant combustion chamber is constructed over the ground surface, by using fire grate. Various openings for bagasse feeding, ash 
removing, and hole for air circulation are provided. At the start of flue gas passage baffle plate is provided. As shown in fig. 9

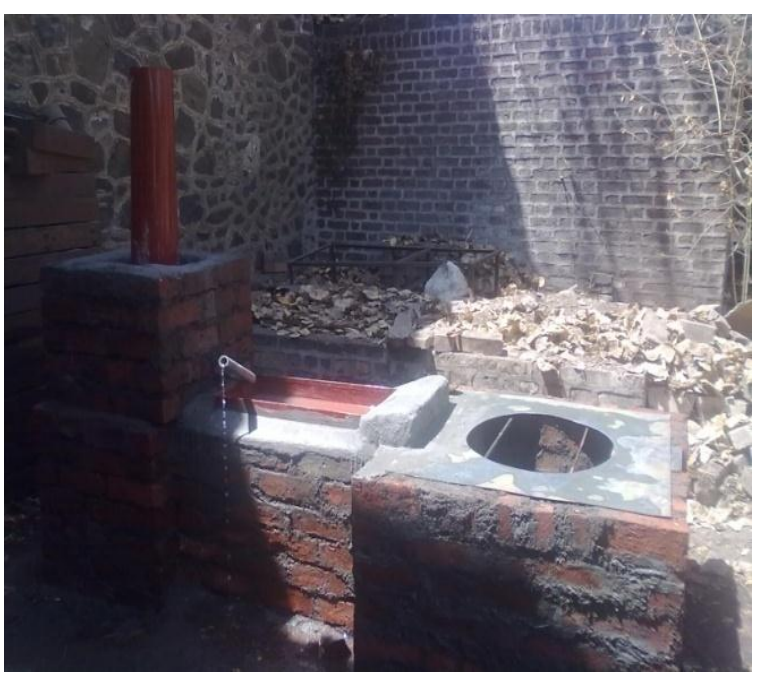

Figure 9: Improved jaggery plant

\subsection{Working}

To achieve desired efficiency there are two steps of operation required, and after that efficiency is constant.

\subsubsection{Step1:}

In first step the juice available at room temperature is poured in boiling pan, economizer, and in pre-heater. Due to burning of bagasse heat is given to the pan and the heat carried by the exhaust gases is extracted by means of heating of juice which is in economizer and in pre-heater, so the temperature of juice increases form initial temperature to certain degree the temperature of juice in economizer is greater than in pre-heater.

The thermal efficiency of the existing furnace was found to be $16.16 \%$ and bagasse used is $2.75 \mathrm{~kg} / \mathrm{kg}$ of jaggery production.

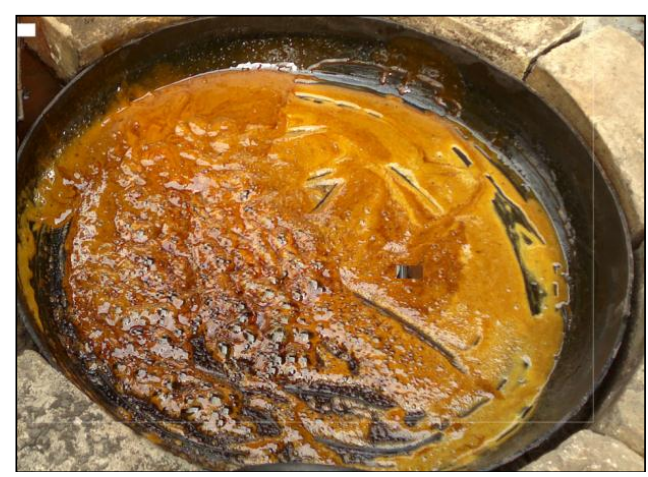

\subsubsection{Step 2:}

Figure 10: Jaggery Produced

In second step, the juice from the economizer and preheater is poured in boiling pan and fresh juice is poured in Economizer. The energy required is less as compare to the step one.

\subsection{Observations}

i. Mass of sugarcane juice per batch $=2 \mathrm{~kg}$

ii. Mass of bagasse required per batch $=0.9 \mathrm{~kg}$

iii. Mass of jaggery produced per batch $=0.425 \mathrm{~kg}$

iv. Mass of slag (mud) removed per batch $=0.025 \mathrm{~kg}$

v. Mass of water evaporated per batch $=1.55 \mathrm{~kg}$

vi. Initial room temperature of furnace $=33^{\circ} \mathrm{C}$.

vii. Initial temperature of juice $=50^{\circ} \mathrm{C}$.

viii. Final temperature of juice $=95^{\circ} \mathrm{C}$

ix. Pre-Heater temperature $=60^{\circ} \mathrm{C}$

xi. Economizer Temperature $=45^{\circ} \mathrm{C}$

Flue gas temperature $=144^{\circ} \mathrm{C}$

Time required for one batch $=15 \mathrm{~min}$

\subsection{Calculations}

i. Heat energy input per batch $=\mathrm{mb}^{*} \mathrm{Cb}$

$$
\begin{aligned}
& =2 * 16000 \\
& =36000 \mathrm{MJ}
\end{aligned}
$$

ii. Energy required for heating the juice:

$$
\begin{aligned}
& =\mathrm{mj}^{*} \mathrm{CPw}^{*}(\mathrm{Tj}-\mathrm{Ta}) \\
& =544.31 \mathrm{MJ}
\end{aligned}
$$

Latent heat of water $=2270 \mathrm{~kJ} / \mathrm{kg}$

iii. Mass of water evaporated per batch:

Mass of jaggery produced $=$ mass of juice - mass of

water evaporated - mass of slag

$$
\begin{aligned}
& 0.425=2-\mathrm{M}_{\mathrm{w}}-0.02 \\
& \mathrm{M}_{\mathrm{w}}=1.55 \mathrm{~kg}
\end{aligned}
$$

iv. Total latent heat of vaporization of water :

$$
\begin{aligned}
=\mathrm{Mw}^{*} \mathrm{hfg} \\
=3520.05 \mathrm{KJ}
\end{aligned}
$$

v. Total heat $=3947.124 \mathrm{KJ}$

vi. Thermal efficiency $=$ Heat output/ Heat Output

vii. Thermal efficiency $=3947.124 / 18000$

viii. Thermal efficiency $=24.36 \%$

The thermal efficiency of improved furnace was found to be $24.36 \%$ and bagasse consumption is $1.7 \mathrm{~kg} / \mathrm{kg}$ of jaggery production.

\section{Result}

In order to evaluate the system performance of jaggery making furnace, various details such as Jaggery Production, production time and juice recovery etc were observed. The temperature of juice during boiling and the temperature of flue gas were also observed. A model of jaggery making furnace was constructed in the workshop.

The collected data for traditional and improved furnace is given in the Table1. 
Table1. Comparison between Conventional and improved Jaggery furnace.

\begin{tabular}{|c|c|c|c|}
\hline $\begin{array}{c}\text { Sr. } \\
\text { No. }\end{array}$ & Particulars & $\begin{array}{c}\text { Trad. } \\
\text { furnace }\end{array}$ & $\begin{array}{c}\text { Impr. } \\
\text { Furnace }\end{array}$ \\
\hline 1 & $\begin{array}{c}\text { Mass of sugarcane juice per batch } \\
\text { in Kg }\end{array}$ & 2 & 2 \\
\hline 2 & $\begin{array}{c}\text { Mass of bagasse required per } \\
\text { batch in Kg }\end{array}$ & 1.23 & 0.9 \\
\hline 3 & $\begin{array}{c}\text { Mass of jaggery produced per } \\
\text { batch in Kg }\end{array}$ & 0.425 & 0.425 \\
\hline 4 & $\begin{array}{c}\text { Mass of slag (mud) removed per } \\
\text { batch in Kg }\end{array}$ & 0.025 & 0.025 \\
\hline 5 & $\begin{array}{c}\text { Mass of water evaporated per } \\
\text { batch In Kg }\end{array}$ & 1.55 & 1.55 \\
\hline 6 & $\begin{array}{c}\text { Initial room temperature of } \\
\text { furnace in }{ }^{\circ} \mathrm{C}\end{array}$ & 33 & 33 \\
\hline 7 & Initial temperature of juice in ${ }^{\circ} \mathrm{C}$ & 30 & 50 \\
\hline 8 & Final temperature of juice in ${ }^{\circ} \mathrm{C}$ & 95 & 95 \\
\hline 9 & Flue gas temperature in ${ }^{\circ} \mathrm{C}$ & 240 & 144 \\
\hline 10 & $\begin{array}{c}\text { The temperature of furnace } \\
\text { during combustion in }{ }^{\circ} \mathrm{C}\end{array}$ & 650 & 650 \\
\hline 11 & $\begin{array}{c}\text { Time required for one batch in } \\
\text { min }\end{array}$ & 22 & 15 \\
\hline 12 & Jhermal Efficiency in $\%$ & 16.16 & 24.36 \\
\hline 13 & $\begin{array}{c}\text { Bagasse Consumption per Kg of } \\
\text { Jaggery in Kg }\end{array}$ & 2.9 & 1.7 \\
\hline
\end{tabular}

\section{References}

Vision 2030: Indian Institute of Sugarcane Research Lucknow, 2011 (Chapter 1).

PVK Jagannadha, Madhusweta Das and SK Das, Jaggery, a Traditional Indian Sweetener, Indian Journal of Traditional Knowledge, Vol. 6(1), January 2007, pp 95- 102

Techno-Economic Analysis of Jaggery Production in Maharashtra: Indian Institute of Technology, Bombay, 2012, (Chapter 1, 2).

Kiran Y. Shiralkar, Sravan K. Kancharla , Narendra G. Shah, Sanjay M. Mahajani, Energy improvements in jaggery making process, Elsevier: Energy for Sustainable Development, 2013.

Ganesh B. Agalave, Performance Improvement of a Single Pan Traditional Jaggery Making Furnace by Using Fins and Baffle, International Journal of Advance Research In Science And Engineering, IJARSE, Vol. No.4, Issue 04, April 2015. 